\title{
Kenaf (Hibiscus cannabinus L., Malvaceae) Research and Development Advances in Bangladesh: A Review
}

\section{Md. Mahbubul Islam}

Chief Scientific Officer \& Head, Planning, Training and Communication Division of Bangladesh Jute Research Institute, Manik Mia Avenue, Dhaka..

Corresponding Author: Md. Mahbubul Islam, Chief Scientific Officer \& Head, Planning, Training and Communication Division of Bangladesh Jute Research Institute, Manik Mia Avenue, Dhaka.E-mail: mahbub_agronomy@yahoo.com, csoagronomy@bjri.gov.bd

Received date: September 02, 2019; Accepted date: September 12, 2019; Published date: September 18, 2019

Citation: Mahbubul Islam. (2019) Kenaf (Hibiscus cannabinus L., Malvaceae) Research and Development Advances in Bangladesh: A Review. J.Nutrition and Food Processing, 2(1); DOI: 10.31579/2637-8914/010

Copyright:@2019 Mahbubul Islam, This is an open-access article distributed under the terms of the Creative Commons Attribution License, which permits unrestricted use, distribution, and reproduction in any medium, provided the original author and source are credited.

\begin{abstract}
Kenaf [1] originated in India and Africa the plant is best grown in tropics and to some extent in sub-tropics. In Bangladesh, Kenaf is now a promising new fibre crop. Around 0.08-0.09million tons of kenaf produced in the country from 0.04 million hectares of land. The secondary data of kenaf used here were collected from different studies like national and international annual reports, thesis, books and journals during from January to July 2019. The plants are herbaceous annuals; growing to a height of even $5 \mathrm{~m}$. There are some Kenaf varieties of bnagladesh, HC-2, HC-95, BJRI Kenaf-3(Bot Kenaf) and BJRI Kenaf -4 (KE-3). The commercial success of kenaf has important potential economic and environmental benefits in the areas of soil remediation, toxic waste cleanup, removal of oil spills on water, reduced chemical and energy use for paper production, greater recycled paper quality, reduced soil erosion due to wind and water, replacement or reduced use of fiberglass in industrial products, and the increased use of recycled plastics. In Bangladesh day by day demand of kenaf fibre is increasing. Kenaf uses in fibre, forage, paper pulp and also where kenaf is grown in home gardens, the more tender upper leaves and shoots are sometimes eaten either raw or cooked. Kenaf fruits have significant medicinal properties, very high in vitamin-C, antioxidants and phytochemicals. It's seeds are a good source of fat slouble antioxidants. In future research to be continued for searching kenaf varieties tolerance to problem soil; tolerance to diseases and pests; having small seed size with long duration of seed viability and smoothness and indehiscence type of kenaf fruits.
\end{abstract}

Key Words: kenaf, history; botany; cultivation; research and development, uses, future approach

\section{Introduction}

Kenaf (Hibiscus cannabinus L., Malvaceae) is a warm season annual fiber crop closely related to White Jute (Corchorus capsularis L.) that can be successfully produced in mainly in India and China, followed by Bangladesh. As the commercial use of kenaf continues to diversify from its historical role as a cordage crop (rope, twine, and sackcloth) to its various new applications including paper products, building materials, absorbents, and livestock feed, choices within the decision matrix will continue to increase and involve issues ranging from basic agricultural production methods to marketing of kenaf products. These management decisions will require an understanding of the many different facets of kenaf production as a fiber, feed, and seed crop. It is an annual, non-wood fiber plant indigenous to central Africa. Akin to okra and cotton, kenaf grows to heights of 12 to 18 feet in a six-month growing season. Kenaf produces 5 to 10 tons of dry fiber per acre, consisting of external bast fibers (about $1 / 3$ of the plant) and internal core fibers (the remaining $2 / 3$ of the plant). Uses of the fiber range from paper, grass mats, fiberglass substitutes, animal bedding, oil-absorbent materials, chicken and cat litter, animal forage, particle board, and potting soil, to name a few. At present, in Bangladesh, so many areas are covered by Kenaf like, Bhrambaria, Voirab, Netrokona, vast areas of Kishoregonj; Laksmipur, Noakhali, Shriatpur, Madaripur, some sporadic areas of Tangail, Mymensingh and Jamalpur.

In Bangladesh, Kenaf [1] is a promising new fibre crop. Around 0.080.09

Auctores Publishing-Volume2(1)-010www.auctoresonline.org Page-1 million tons of kenaf produced in the country from 0.04 million hectares of land [1]. The name kenaf is of Persian origin and is most generally used to describe the plant Hibiscus cannabinus L. and the fibre. Miyake and Suzuta [2] compliled a list of 129 world wide names that have been given this plant. In India the common name in Bengal is Mesta; in Madras it is called palungi; in Western India and Taiwan it is known as ambari; in Bombay, decean hemp; in Andhra Pradesh it is known as Bimli jute or Bimlipatam jute; in Egypt and northern Africa it is varioyusly called til, teel, or teal; in Indonesia it is known as Java jute; in Brazil as papoula de sao Francisco; in South Africa, stokroor ("wild stock rose); in Wesdt Africa it is known as dah, gambo, and rama. Kenaf, (species Hibiscus cannabinus), fast-growing plant of the hibiscus, or mallow, family (Malvaceae) and its fibre, one of the bast fibre group. It is used mainly as a jute substitute. The plant grows wild in Africa, where the fibre is sometimes known as Guinea hemp, and has been cultivated on the Indian subcontinent, where it is usually known as mesta, or ambari, since prehistoric times.

Kenaf was unknown in the West until late in the 18th century, when cordage and sacking made from the fibre were brought to Europe. It remained one of the less important bagging materials until World War II, when shortages of jute and other bagging fibres led to a new interest that continued after the war, as supplies of established materials remained insufficient and prices increased. In Cuba, the United States, and similarly affected countries, governments encouraged cultivation of kenaf, and production became increasingly mechanized. The plant is an herbaceous annual with stalks growing to about 18 feet (5.5 metres) in height and fibre concentrated mainly in the lower portion. The leaves are composed of five 


\section{J Nutrition and Food Processing}

lance-shaped lobes occurring mainly near the stalk top; the flowers, pale yellow with purple centres, are borne on short stalks growing from the upper angles between leaf stalks and stems.

Kenaf, although adaptable to various soils, grows best in well-drained, sandy loam and requires a warm, moist climate, tropical or subtropical, without excessively heavy rains or strong winds. Some varieties need at least 12 hours of light each day throughout the growing season. Kenaf is less demanding on the soil than jute and may be grown in rotation with other crops. Dense sowing is common, except when cultivation is for seed production. Crops are hand-harvested, yielding the best fibre at the flowering stage. Fibres are usually separated from the stalks mechanically, although in some areas retting, followed by hand stripping, is still practiced. The fibre strands, about 3 feet $(0.9$ metre) long, are pale in colour and lustrous, with strength comparable to that of jute. Leading producers include India, Thailand, and China. Kenaf, still fairly new to international trade, is used mainly for cordage, canvas, and sacking but is receiving increased consideration for other products, such as newsprint and carpet-backing yarn. Studies begun in the 1950s demonstrated that kenaf, which reaches its mature height in less than six months, is easier to process, produces a higher yield, and has stronger fibres than plants grown for wood chips.

\section{History of Kenaf}

Kenaf has been used as a cordage crop to produce twine, rope, and sackcloth for over six millennia. Kenaf was first domesticated and used in northern Africa. India has produced and used kenaf for the last 200 years, while Russia started producing kenaf in 1902 and introduced the crop to China in [3]. In the United States, kenaf research and production began during World War II to supply cordage material for the war effort [4]. The war not only interrupted the foreign fiber supplies from countries such as the Philippines, but the US involvement in the war also increased the use of these fibers by the US. Once it was determined that kenaf was a suitable crop for US production, research was initiated to maximize US kenaf yields. Asa result, scientists successfully developed high-yielding anthracnose-resistant cultivars, cultural practices, and harvesting machinery that increased fiber yields $[5 ; 6]$.

Then in the 1950s and early 1960s, as USDA researchers were evaluating various plant species to fulfill future fiber demands in the US, it was determined that kenaf was an excellent cellulose fiber source for a large range of paper products (newsprint, bond paper, and corrugated liner board). It was also determined that pulping kenaf required less energy and chemical inputs for processing than standard wood sources [7]. More recent research and development work in the 1990s has demonstrated the plant's suitability for use in building materials (particle boards of various densities, thicknesses, with fire and insect resistance), adsorbents, textiles, livestock feed, and fibers in new and recycled plastics (injected molded and extruded) [8].

\section{Habitat and Distribution}

Originated in India and Africa the plant is best grown in tropics and to some extent in sub-tropics. Kenaf grow almost throughout the world both in tropical and temperate areas it is sensitive to frost. In India, kenaf is grown often as a border crop in garden areas where the soil is loamy and affords good drainage. It is grown mixed with most cereals in dry lands or as a pure crop. Kenaf is an important fibre crop in South India. It is cultivated as a rainfed crop in large areas in Madhya Pradesh, Andhra Pradesh and Tamil Nadu. It is sown on the bunds of irrigation channels and in small patches in garden lands.

\section{Kenaf Cultivation in Bangladesh}

Geographical localization of the agricultural production area for Kenafvarieties used in the Kenaf-based fiber composites value chain (Kenaf with sufficient quality for the fibre properties of tenacity, elongation and cleanness- please confer with NFC for the specific quality requirements). Agricultural production areas of Kenaf-varieties in Bangladesh are Brammanbaria, Voirab, vast areas of Kishoregonj; Lakkhipur, Shriatpur, Madaripur, some sporadic areas of Tangail, Mymensingh and Jamalpur.

\begin{tabular}{|c|c|c|c|c|c|c|}
\hline Districts & 2012 & 2011 & 2010 & 2009 & 2008 & 2007 \\
\hline Greater Dhaka & 4165 & 5084 & 7157 & 0 & 0 & 0 \\
\hline $\begin{array}{l}\text { Kishoreganj, } \\
\text { Netrokona, } \\
\text { Sherpur, Jamalpur }\end{array}$ & 10016 & 11626 & 7502 & 1206 & $\begin{array}{r}628 \\
\text { Jamalpur }\end{array}$ & 507 \\
\hline Brammanbaria & 485 & 537 & 488 & 75 & 269 & 364 \\
\hline Lakhsmipur & 107 & 55 & 36 & 30 & 0 & 0 \\
\hline Shariotpur & 4369 & 4436 & 4412 & 2485 & 2450 & 2140 \\
\hline
\end{tabular}

Table 1: Area under Kenaf in different growing location of Bangladesh (Hectare) Source: Dept. of Agril. Extension

\begin{tabular}{|c|c|c|c|c|c|c|}
\hline$[=[$ Total & 2012 & 2011 & 2010 & 2009 & 2008 & 2007 \\
\hline Bangladesh & 19144 & 21795 & 19595 & 3769 & 3347 & 6530 \\
\hline
\end{tabular}

Table 2: Total area under Kenaf in Bangladesh in different year (Hectare) 


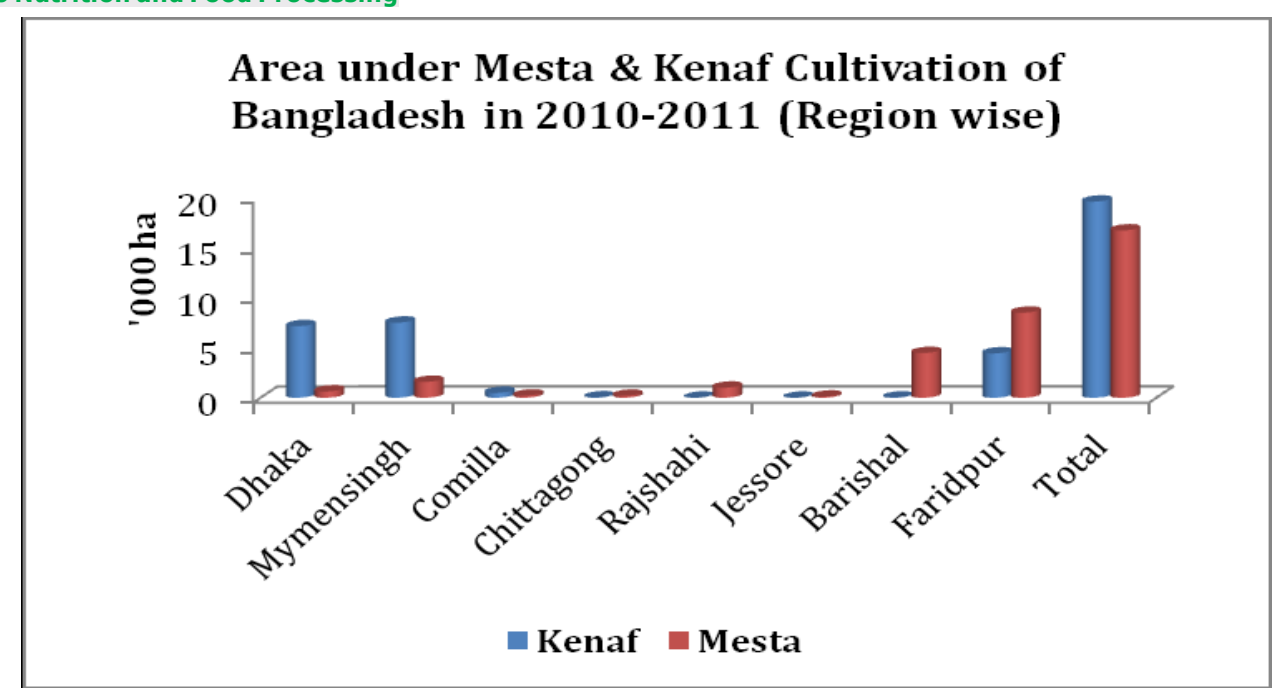

Figure 1: Area under Mesta and Kenaf cultivation of Bangladesh in 2010-2011 (Region wise)

\section{Materials and Methods}

The study was based on secondary information. The secondary data used were collected from different studies of the Library of Bangladesh Jute Research Institute, Dhaka during from January to June 2019. These secondary data were BJRI annual reports, different thesis, Books, Bangladesh Journal of Jute and Fiber Research, Jute and Jute Fabrics, Bangladesh (News letter) of BJRI and other national and international journals.

\section{Results and Discussion}

\section{Taxonomy}

\begin{tabular}{|c|c|}
\hline \multicolumn{2}{|c|}{ Scientific classification } \\
\hline Kingdom: & Plantae \\
\hline Clade: & Angiosperms \\
\hline Clade: & Eudicots \\
\hline Clade: & Rosids \\
\hline Order: & Malvales \\
\hline Family: & Malvaceae \\
\hline Genus: & Hibiscus \\
\hline Species: & H. cannabinus \\
\hline \multicolumn{2}{|c|}{ Binomial name } \\
\hline \multicolumn{2}{|c|}{ Hibiscus cannabinus L. } \\
\hline \multicolumn{2}{|c|}{ Synonyms } \\
\hline & $\begin{array}{l}\text { is congener Walp. } \\
\text { s verrucosus Walp. } \\
\text { cannabina Ulbr. } \\
\text { avanillesii Kostel. } \\
\text { alangensis Baker } \mathrm{f} \text {. } \\
\text { nderystii De Wild. } \\
\text { olius Mill. no. illeg. }\end{array}$ \\
\hline
\end{tabular}

Source: http://www.britannica.com/EBchecked/topic/314686/kenaf

\section{Botany of Kenaf}

The plants are herbaceous annuals; growing to a height of even $5 \mathrm{~m}$. the stems are straight, with small prickles: leaves alternate, stipulate, lobed and with serrated margins,stipules long and pointed: flowers solitary, with short pedicels and axillary, epicalyx stiff, consisting of seven to eight bracteoles: corolla larger, spreading pale yellow or yellow with crimson or purplish centre: stamens numerous on a staminal column: ovary superior, five carpelled: style passes through staminal column and terminate in five stigmatic branches: fruit capsule, five loculed each containing four to five seeds. It is mainly as self-pollinated crop. Kenaf is a short day, annual, herbaceous plant cultivated for the soft bast fibre in the stem. It belongs to the Malvaceae, a family notable for both its economic and horticultural importance [9]. The genus Hibiscus is widespread, comprising some 200 annual and perennial species [10]. Kenaf is closely related to cotton and the holly hocks (Althea sp.). A modified morphological description of the species from Bates [9] follows.

Stem: Erect, prickly, cylindrical, branched or un-branched reaching a height of 1 to $4 \mathrm{~m}$, either entirely green green with pinkish or raddish pigmentation, or red.

Leaves: Eigher entirely cordated and very shallowly lobed with serrated margins or 3-5-7 deeply palmate, alternate, stipulate, stipulates free lateral, pubescent 0.5 to $0.8 \mathrm{~cm}$ long. Petiole 3.0 to $18.0 \mathrm{~cm}$ long, finely pubescent on the adaxial surface and bristled on the abaxial surface, green to red, scabrous.

Lamina: Lobed or unlobed, when unloobed ovagte margin serrated, apex acuminagte, 5-7 nerved palmately reticulate, when lobed palmately 5-7 deep, each lobe lanceolate, margin serrated, apex acute, one green gland present on the mid-vein on the under surface, upper surface glabrous, lower surface hairy along with veins, scaberulous.

Flowers: Salitary, axillary, pedunculate, pednecle 0.2 to $0.4 \mathrm{~cm}$ long, bristled, pentamerous, 8.0 to $10.0 \mathrm{~cm}$ in diameter when open, yellow with red center or completely yellow, showy, bractoles (epicalyx) 7-9, segmented, linear, bristled, 1.0 to $1.5 \mathrm{~cm}$ long, green attached to the base of the calyx.

Calyx: Cepals 5, lanceolate, cornate below the middle into a cap, green bristled and tormentosed with a large green gland on the back of each sepal, persistent.

Corolla: Large, spreading, bell shaped, full yellow with or without deep enter, petals 5, free, very slightly united at the base twisted outer side pubescent, 7-9 cm long.

Stamens: Many monadulhous, stamined coluran epipetatous truincate, 2.5 $\mathrm{cm}$ long with glandular hairs, yellow or light red, filaments 0.1 to $0.2 \mathrm{~cm}$ long, red yellow anthers semiform, pollen spiny . 
Carpels: 5, ovary ovoid, 0.7 to $0.8 \mathrm{~cm}$ long. Densely covered weith white silky adpressed hairs, 5, chambered with many ovules in each chamber arranged in 2 vertical rows stigma-5, hairy, capitate, red or yellow, exerted.

Capsule: Ovoid, pointed, villose, half of the length of the calyx with about 20 to 26 seeds.
Seed: Traiangular, angles more or less acute, ash gray with pointed light yellowish warty spots. Hilum brown, relatively small. Most of the better known kenaf varieties produce seed that range from 36000 to 40000 per kg.; however some Africand types from Sadan, Uganda abnd Central African Republic produce small seed that range from 100,000 to 110,000 per kg. Small seeded kenaf types have also been noted in Iran [11].

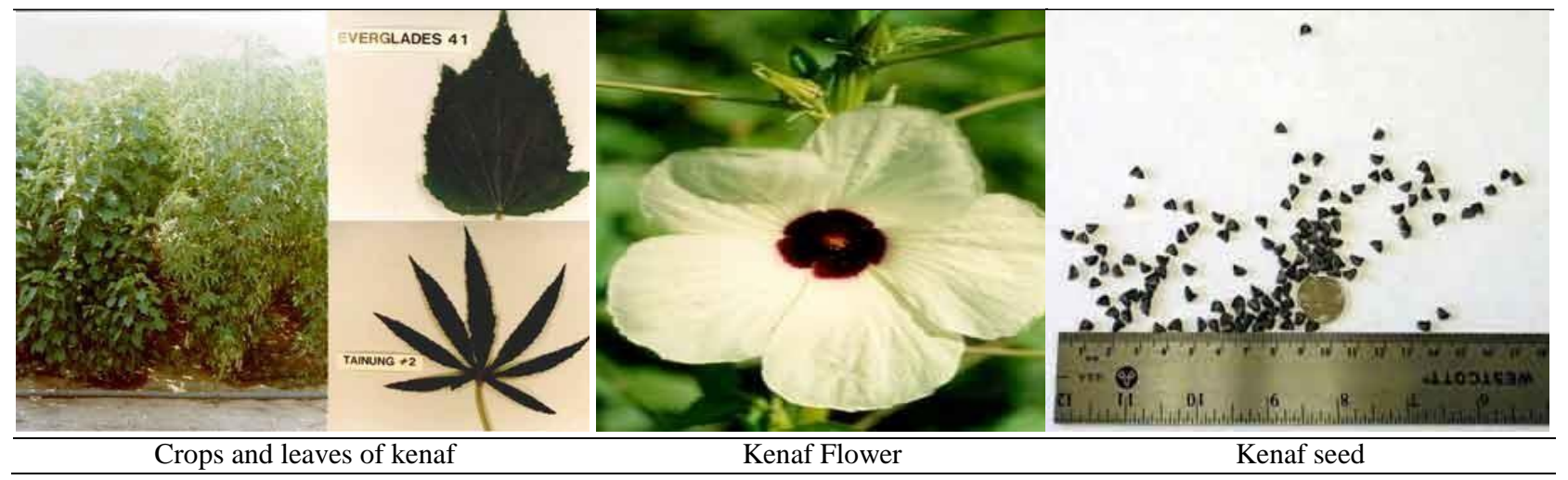

Figure 2. Crops and leaves, flower and seed of Kenaf

\section{Climate}

Kenaf cultivation requires specific climate and land. It requires early rains in March, May and June and intermittent rain and sunlight thereafter till August, temperature between $28^{\circ} \mathrm{C}$ and $35^{\circ} \mathrm{C}$ and humidity between $70 \%$ and $90 \%$. This type of climate is available in areas between $30^{\circ}$ Latitude North and South of the earth.

\section{Soil}

One of kenaf's advantages as a crop, is it can be successfully grown in a wide range of soil types, from high organic peat soils to sandy desert soils. Although kenaf grows better on well-drained, fertile soils with a neutral $\mathrm{pH}$, the crop can withstand late season flooding, low soil fertility, and a wide range of soil $\mathrm{pH}$ values. Kenaf also has shown excellent tolerance to drought conditions.

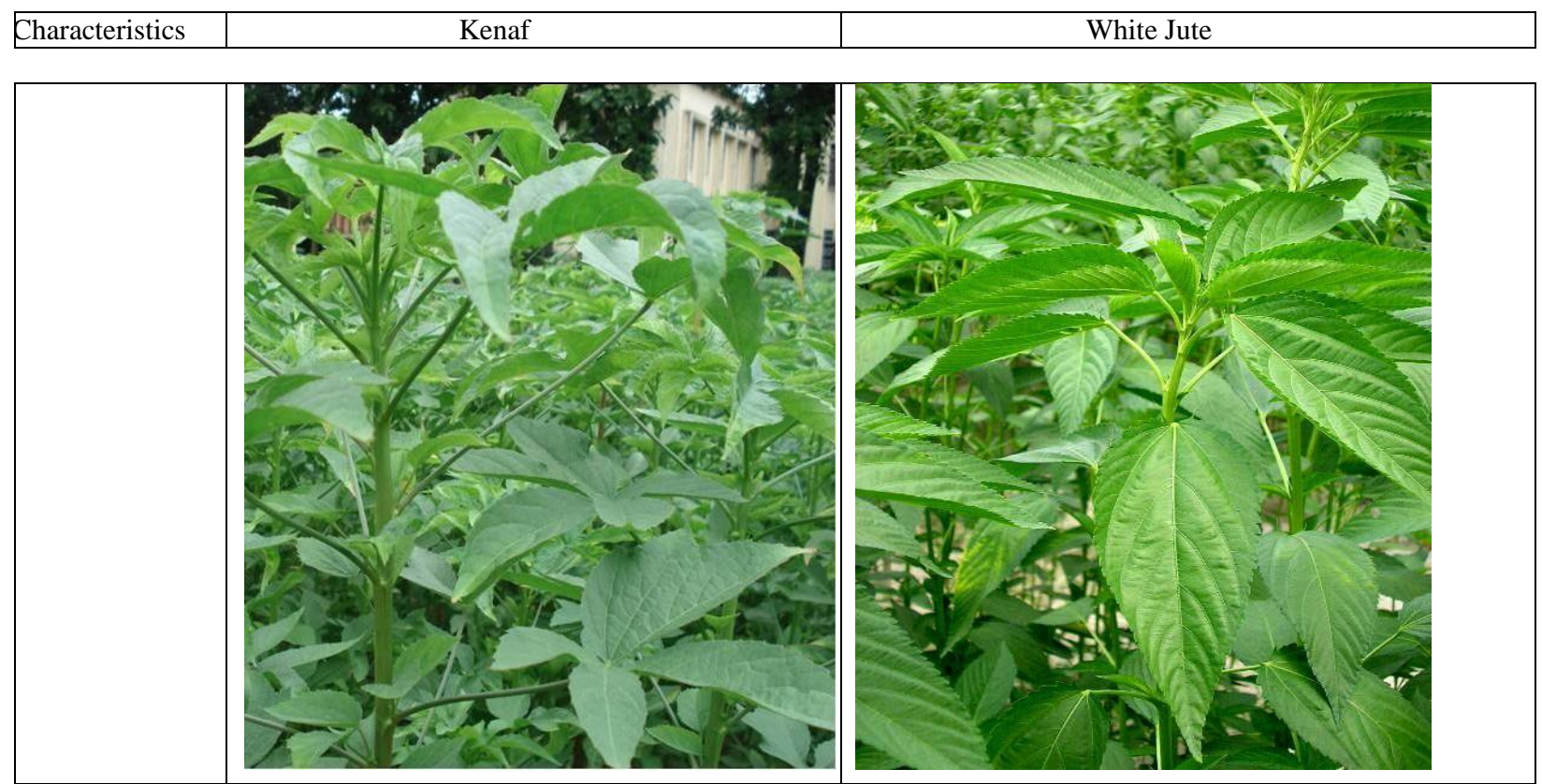

\begin{tabular}{|l|l|l|}
\hline & \multicolumn{1}{|c|}{ Figure 3. Kenaf plant } & \multicolumn{1}{|c|}{ Figure 4. White jute } \\
\hline Stem & $\begin{array}{l}\text { Erect, prickly, cylindrical, branched or un- } \\
\text { branched reaching a height of 1 to 4m, either } \\
\text { entirely green green with pinkish or raddish } \\
\text { pigmentation, or red. }\end{array}$ & $\begin{array}{l}\text { logging in later stages, herbaceous annual, 3-5 month } \\
\text { duration for fibre yield depending upon sowing time. It`s } \\
\text { stem cytindrical, green to dull coppery red to pink, } \\
\text { periderm in the basal portions in later stages. }\end{array}$ \\
\hline
\end{tabular}

\begin{tabular}{|l|l|l|}
\hline Leaves & Eigher entirely cordated and very shallowly & Leaves are glabrous, 5-13 cm by 2.5-8.2 cm length and \\
\hline
\end{tabular}




\begin{tabular}{|c|c|c|}
\hline & $\begin{array}{l}\text { lobed with serrated margins or } 3-5-7 \text { deeply } \\
\text { palmate, alternate, stipulate, stipulates free } \\
\text { lateral, pubescent } 0.5 \text { to } 0.8 \mathrm{~cm} \text { long. Petiole } 3.0 \\
\text { to } 18.0 \mathrm{~cm} \text { long, finely pubescent on the adaxial } \\
\text { surface and bristled on the abaxial surface, green } \\
\text { to red, scabrous. }\end{array}$ & $\begin{array}{l}\text { breight. Ovate oblong, acuminate, coarsely toothed, } \\
\text { lower most pair of serrations enlarged and end in hairy } \\
\text { appendages. Petiole } 4-8 \mathrm{~cm} \text {, various from green to pink in } \\
\text { different varieties, stipules } 0.5-2.0 \mathrm{~cm} \text { or more, foliaceous } \\
\text { in some varieties, tip coloured or green. }\end{array}$ \\
\hline Flowers & $\begin{array}{l}\text { Salitary, axillary, pedunculate, pednecle } 0.2 \text { to } \\
0.4 \mathrm{~cm} \text { long, bristled, pentamerous, } 8.0 \text { to } 10.0 \\
\mathrm{~cm} \text { in diameter when open, yellow with red } \\
\text { center or completely yellow, showy, bractoles } \\
\text { (epicalyx) } 7-9 \text {, segmented, linear, bristled, } 1.0 \text { to } \\
1.5 \mathrm{~cm} \text { long, green attached to the base of the } \\
\text { calyx. }\end{array}$ & $\begin{array}{l}\text { Flowers are small generally in extra axillary cymes in } \\
\text { groups of } 2-5 \text { or more; } 0.3-0.5 \mathrm{~cm} \text { long and } 0.5-0.6 \mathrm{~cm} \\
\text { wide; sepals 5, coloured or green, petals } 5 \text {, yellow or pale } \\
\text { yellow, stamens } 20-30 \text {; anther yellow to pale yellow, } \\
\text { ovary rounded, 5-carpelled, syncarpous, ovals axile, } \\
\text { usually } 10 \text { in each locales in } 2 \text { rows, giving about } 50 \\
\text { ovules in each ovary; style } 2-4 \mathrm{~mm} \text {; stigma pubescent. } \\
\text { Anthesis one or two harms after sun rise. }\end{array}$ \\
\hline Capsul & $\begin{array}{l}\text { Ovoid, pointed, villose, half of the length of the } \\
\text { calyx with about } 20 \text { to } 26 \text { seeds. }\end{array}$ & $\begin{array}{l}\text { sules rounded, } 1.0-1.5 \mathrm{~cm} \text { in diameter, wrinkled, rarely } \\
\text { smooth, muricate, } 5 \text {-locular, seed- } 7-10 \text { in } 2 \text { rows in } \\
\text { each ocular, without transverse partitions, } 30-50 \text { in each } \\
\text { fruited. }\end{array}$ \\
\hline Seed & $\begin{array}{l}\text { Traiangular, angles more or less acute, ash gray } \\
\text { with pointed light yellowish warty spots. Hilum } \\
\text { brown, relatively small. Most of the better } \\
\text { known kenaf varieties produce seed that range } \\
\text { from } 36000 \text { to } 40000 \text { per kg.; however some } \\
\text { Africand types from Sadan, Uganda abnd } \\
\text { Central African Republic produce small seed } \\
\text { that range from } 100,000 \text { to } 110,000 \text { per kg. }\end{array}$ & $\begin{array}{l}\text { Seeds are small, chocolate brown, } 4-5 \text { faced about } 300 \\
\text { per gm. }\end{array}$ \\
\hline Fibre & Fine fibre with lower weght than Kenaf & rse fibre higher weight than white Jute \\
\hline $\begin{array}{l}\text { Growing } \\
\text { areas }\end{array}$ & $\begin{array}{l}\text { Brammanbaria, Voirab, vast areas of } \\
\text { Kishoregonj; Lakkhipur, Shriatpur, Madaripur, } \\
\text { some sporadic areas of Tangail, Mymensingh } \\
\text { and Jamalpur. }\end{array}$ & $\begin{array}{l}\text { over Bangladesh except Sylhet, Chattagram Hill Tracts, } \\
\text { Southern areas like Barishal, Borguna, Volla, } \\
\text { Piotuakhali, etc }\end{array}$ \\
\hline $\begin{array}{l}\text { Processing } \\
\text { (Post } \\
\text { harvest) }\end{array}$ & Similar processing as jute & ilar processing as Kenaf \\
\hline $\begin{array}{l}\text { Rules and } \\
\text { regulation } \\
\text { s }\end{array}$ & Not at all & es are maintained \\
\hline
\end{tabular}

Table 3. A morphological differences between Kenaf and White Jute

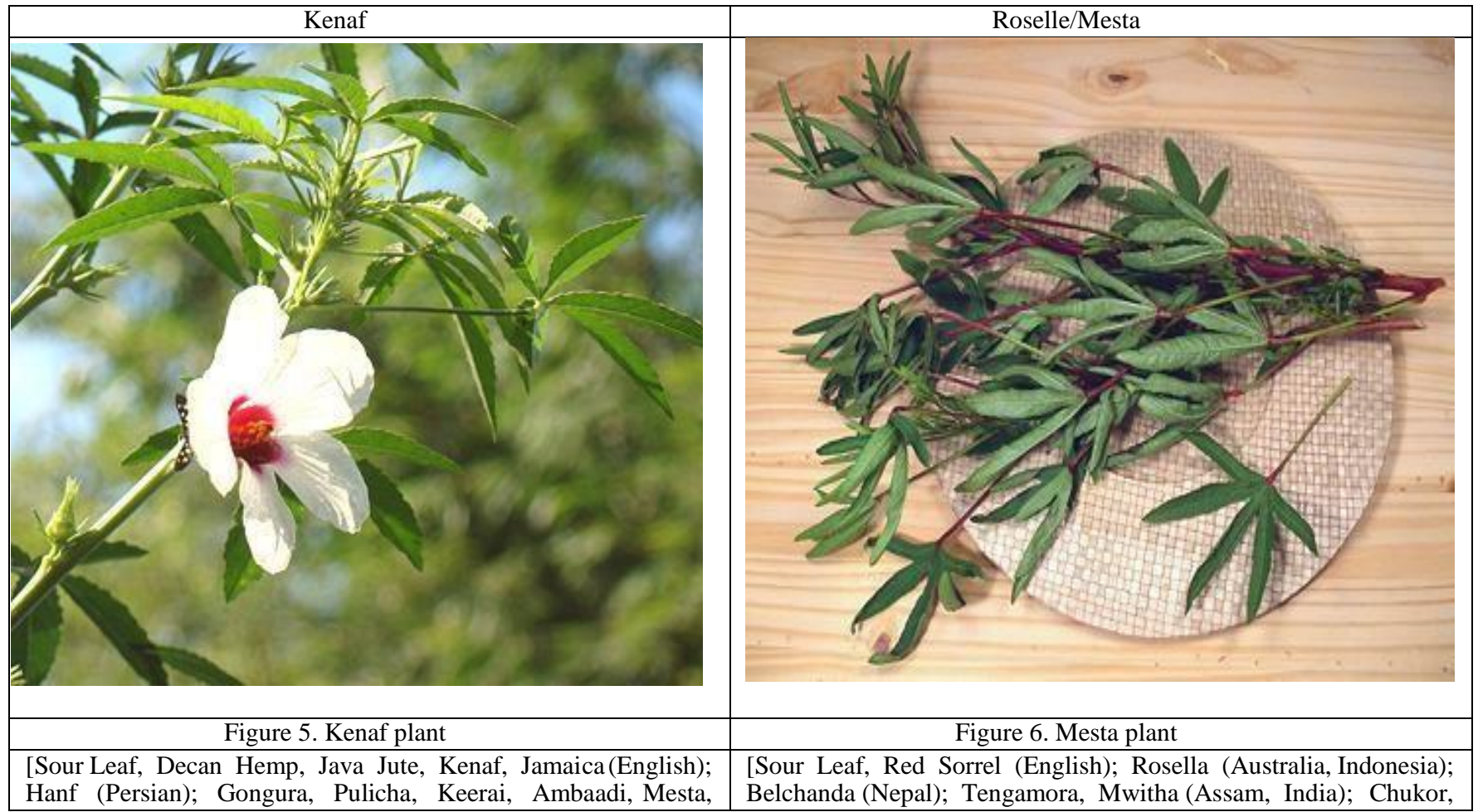


Shougri (India); Teel, Til, Teal (North Africa); Dah, Gambo, Rama (West Africa); Papoula-de-são-francisco, Cãnhamo-brasileiro, Quenafe (Brazil); Cáñamo de la India, Cáñamo de gambo, Cáñamo Rosella, Pavona encendida, Yute de Java, Yute de Siam de gambo, (Spanish); and many, many more; [Hibiscus cannabinus]

This plant, probably originating in South Asia, is cultivated worldwide for many uses: rope fiber, paper, edible leaves, oil, animal feed and bedding, fiberboard, engineered wood and thread for fabrics. The ancient Egyptians used it to make the ropes and sails for their ships. It can grow to about 11 feet tall with stems up to 1 inch diameter. Currently small crops are grown in California, Texas and Louisiana, mostly for animal feed and bedding, but you can expect it to expand as more of its uses are exploited, particularly if hemp remains illegal in the US (hemp has similar fibrous properties but is not related).

The leaves are widely eaten in India, and preferred to the leaves of Roselle, but I haven't seen this plant here in Southern California. The seeds are pressed for cooking oil, which has a very similar fatty acid profile to Cottonseed Oil, but with more Omega 3. It is commonly called Gongura for culinary uses and Kenaf for industrial and fiber uses. This plant is closely related to the smaller, red stemmed Roselle/Gongura (Hibiscus sabdariffa), but has green stems and much different fruit pods. Roselle has wider culinary and medicinal useage.
Gongura, Pulicha, Keerai, Pundi, Ambadi, LalChatni, Kutrum, Mathipuli (India); Chin baung (Burma); KraJiabDaeng (Thailand); Chaye-Torosh (Iran), Karkade (Arabic); Sorrel (Caribbean \& Latin America); Flor de Jamaica (Mexico); Guragod, Labug, Labog (Philippines); Bissap (Africa); Hibiscus sabdariffa]

This plant is closely related to the taller, green stemmed Gongura / Kenaf (Hibiscus cannabinus) but Kenaf fruit pods are very different in structure. Like Kenaf, Roselle is primarily a fiber crop, growing to 8 feet tall, but also has a wide variety of culinary and medicinal uses.

The leaves are a very important herb or vegetable in a good part of India (Andhra, Karala, Karnataka, Assam and others), and valued for their iron content. They are used in a wide variety of pickles, dals and curries, particularly goat and mutton curries, but also with chicken and pork. They are also much used in Burma, especially with fish and shellfish, and in Africa, particularly Senegal, where they flavor a recipe for fish and rice.

This plant fruits prolifically. The fruit pod, similar to a short stubby okra pod, is surrounded by a calyx of dark red petal like sepals. There are two styles, the short one (photo) and the long one where the points around the base are also long.

The sepals could be used in salads as a color accent, but the pod is not particularly edible due to the many stiff fibers it contains. It is almost edible raw, but cooking hardens the sharp fibers while softening the pod, and the seeds remain quite stiff, quite unpleasant. They are, however, used by the Shan people in Burma as a souring agent in stews.

Simmering the whole calyces in water produces a brilliant crimson broth that is just a little sour and quite pleasant enough to serve as the basis for herb teas. It is best to remove the pod, which can make the broth a bit mucilaginous - it's related to okra, after all. The calyces contains enough pectin that jam can be made from them using only sugar and calyces.

Table 4: Differences between Kenaf and Roselle/Mesta

\begin{tabular}{|l|c|c|}
\hline & Kenaf & White Jute \\
\hline Green Plants & $36019 \mathrm{~kg}(100 \%)$ & $34 \mathrm{mt} / \mathrm{ha}(100 \%)$ \\
\hline Green leaves & Attached 5155 kg (14.2\%) & $5304 \mathrm{~kg}(15.6 \%)$ \\
\hline Green Ribbons & $12246 \mathrm{~kg}(34.0 \%)$ & $13688 \mathrm{~kg}(40.2 \%)$ \\
\hline Green Wood & $18658 \mathrm{~kg}(51.8 \%)$ & $15028(44.2 \%)$ \\
\hline Dry leaves & $1176 \mathrm{~kg}(3.26 \%)$ & $1326 \mathrm{~kg}(2.9 \%)$ \\
\hline Dry Ribbons & $3429 \mathrm{~kg}(9.51 \%)$ & $3788 \mathrm{~kg}(11.2 \%)$ \\
\hline Dry wood & $5747 \mathrm{~kg}(15.95 \%)$ & $4250 \mathrm{~kg}(12.5 \%)$ \\
\hline Dry retted fibre & $1742 \mathrm{~kg}(4.83 \%)$ & $2006 \mathrm{~kg}(5 / 9 \%)$ \\
\hline
\end{tabular}

Table 5: Comperison of Kenaf and White jute in different characters

\begin{tabular}{|c|c|c|c|}
\hline & $\begin{array}{l}\text { Whole } \\
\text { kenaf }\end{array}$ & $\begin{array}{l}\text { Kenaf } \\
\text { bast }\end{array}$ & $\begin{array}{l}\text { Kenaf } \\
\text { core }\end{array}$ \\
\hline Fibre length (mm) & 1.28 & 2.6 & 0.6 \\
\hline Diameter (microns) & & 20 & 30 \\
\hline Lignin $(\%)$ & 13.2 & 7.7 & 17.4 \\
\hline
\end{tabular}

Table 6: Kenaf Fibre Characteristics 


\begin{tabular}{|c|c|c|c|}
\hline S1 No & Varieties & Released year & Pedigree \\
\hline \multicolumn{4}{|c|}{ Kenaf (Hibiscus canabinus) } \\
\hline 1. & $\mathrm{HC}-2$ & 1977 & PLS \\
\hline 2. & $\mathrm{HC}-95$ & 1995 & PLS \\
\hline 3. & HC-3 (Bot kenaf) & 2010 & PLS \\
\hline 4. & BJRI Kenaf-4 (KE-3) & 2017 & PLS \\
\hline
\end{tabular}

Table 7: List of varieties of Kenaf crop of Bangladesh

\section{Identifying characters of different Kenaf varieties developed by BJRI in Bangladesh}

\section{Kenaf varieties (Hibiscus canabinus $\mathbf{L}$.}

HC-2 (Joly kenaf): HC-2 was released in 1977. Its stem green pigmented and petiole green, leaves simple cordated, petiole is longer than lamina. Fruit capsule ovoid, indehiscent, seeds subreniform grayish brown. Bright fibre. Medium to medium low land is suitable for cultivation. Seed sowing time mid March to mid April. Seed rate $12-15 \mathrm{~kg} / \mathrm{ha}$. Plant height 4.00 to 5.50 meter. Fibre recovery $7.3 \%$. Time of flowering $150-165$ days after sowing. Time of harvest 120 days after harvest or as per need. Yield 2.50-2.70 t/ha at Research station. The variety suitable for medium low, less fertile and flood affected land. Fibre is bright and shiny. Green plants are excellent raw materials for paper pulp. Tolerant to water logging [12].

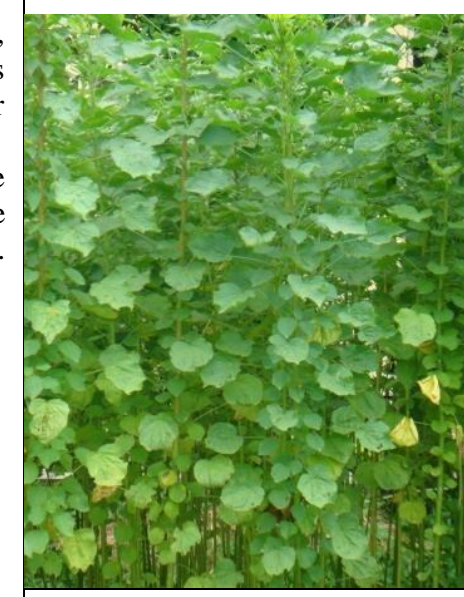

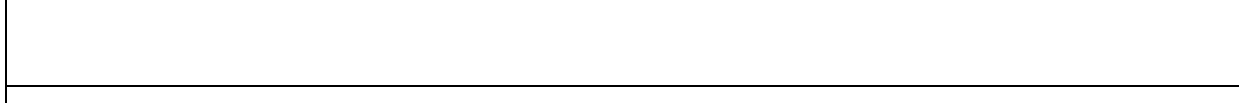

BJRI Kenaf-2 (HC-95): BJRI Kenaf-2 was released in 1995. Its stem tall cylindrical, unbranched, whole plant deep green, Fibre bright. leaves lobed, the petal is light cream colour with very light pink tinge on the inner basal part of the petals. Fruit capsule ovoid, indehiscent, seeds subreniform grayish brown. Medium to medium low land. Loom or slightly clay to sandy loam are suitable for cultivation. Seed sowing time Mid March to Mid April. Seed rate 12-15 $\mathrm{kg} / \mathrm{ha}$. Plant height 3.50 to 4.00 meter. Fibre recovery $6.23 \%$. Time of flowering $150-170$ days after sowing. Time of harvest 120 days after harvest or as per need. Yield 2.80-3.30 t/ha at Research station. This variety is suitable for medium low, less fertile and flood affected land. Fibre is bright and shiny. Green plants are excellent raw materials for paper pulp, seeds contain about $20 \%$ edible oil. Tolerant to water logging [12].

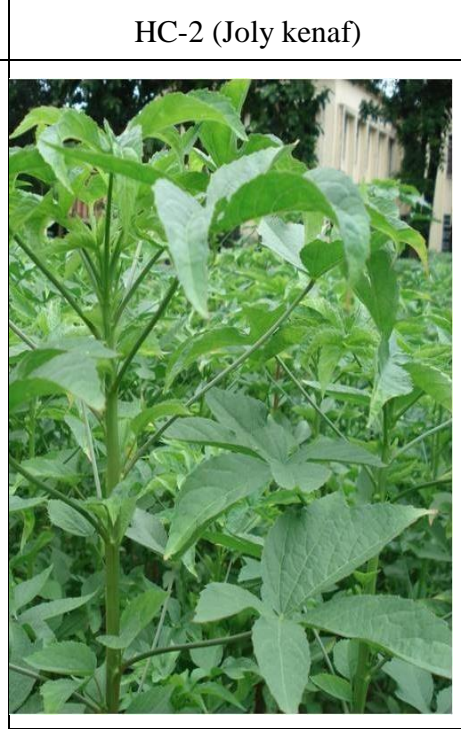


BJRI Kenaf-3 (Bot Kenaf): BJRI Kenaf-3 was released in 2010. Its stem tall cylindrical, unbranched, whole plant deep green, Fibre bright. leaves cordated, the petal is light cream colour with very light pink tinge on the inner basal part of the petals. Fruit capsule ovoid, indehiscent, seeds subreniform grayish brown. Medium to medium low land. Loom or slightly clay to sandy loam are suitable for cultivation. Seed sowing time 15 March to 30 April. Seed rate $12-15 \mathrm{~kg} / \mathrm{ha}$. Plant height 3.50 to 4.00 meter. Fibre recovery $6.53 \%$. Time of flowering 150-170 days after sowing. Time of harvest 120 days after harvest or as per need. Yield 2.60$3.00 \mathrm{t} / \mathrm{ha}$ at Research station. This variety is suitable for medium low, less fertile and flood affected land. Fibre is bright and shiny. Green plants are excellent raw materials for paper pulp, Tolerant to water logging [12].

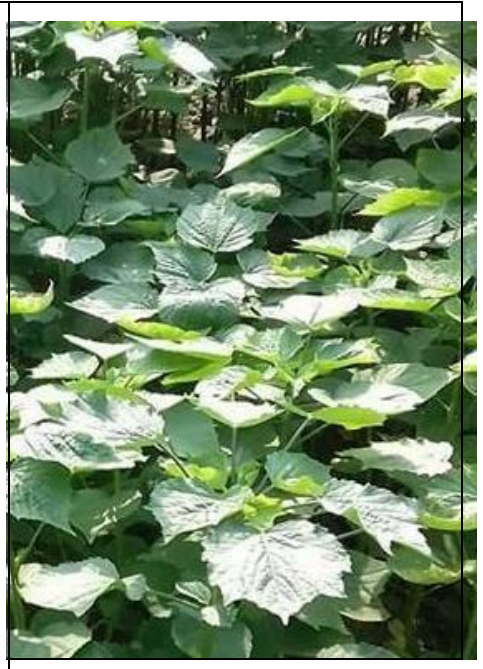

BJRI Kenaf-3 (Bot Kenaf)

BJRI Kenaf-4 (KE-3): BJRI Kenaf-4 was released in 2017. Its stem tall cylindrical, unbranched, whole plant deep green, Fibre bright. leaves lobed, the petal is light cream colour with very light pink tinge on the inner basal part of the petals. Fruit capsule ovoid, indehiscent, seeds subreniform grayish brown. Medium to medium low land. Loom or slightly clay to sandy loam are suitable for cultivation. Seed sowing time 15 March to 15 May. Seed rate $12-15 \mathrm{~kg} / \mathrm{ha}$. Plant height 3.50 to 4.00 meter. Fibre recovery $6.75 \%$. Time of flowering 140-160 days after sowing. Time of harvest 120 days after harvest or as per need. Yield 2.80-3.30 t/ha at Research station. This variety is suitable for medium low, less fertile and flood affected land. Fibre is bright and shiny. Green plants are excellent raw materials for paper pulp, Tolerant to water logging [12].

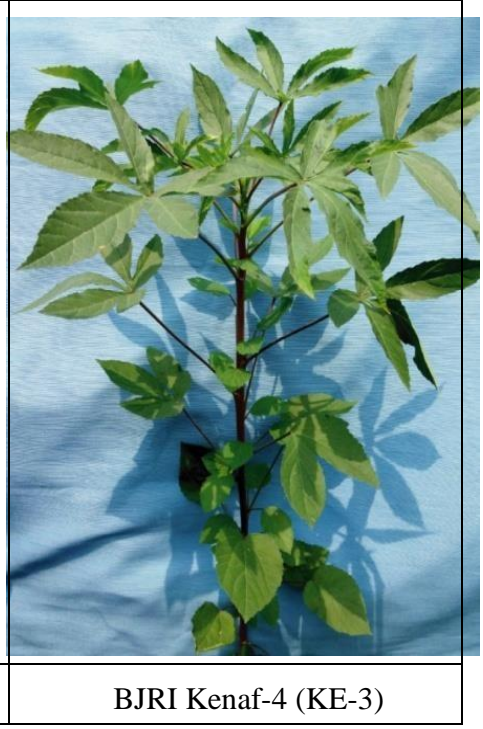

\section{Research and Development works at BJRI}

Mamun et al., [13] reported that among the 94 Acc., twenty seven genotypes viz. Acc. 4410, Acc. 5080, Acc. 4380, Acc. 5016, Acc. 4197, Acc. 1612 , Acc. 4383 , Acc. 1571 , Acc. 5114, Acc. 4897, Acc. 1595, Acc. 1600, Acc. 1601, Acc. 1611, Acc. 1823, Acc. 1824, Acc. 1983, Acc. 1986, Acc. 3746 , Acc. 4115 , Acc. 4345 , Acc. 4443, Acc. 4447, Acc. 4461, Acc. 4623, Acc. 5006 and Acc. 5018 showed better performance than the control varieties HC-95 and BJRI Kenaf-3 in respect of plant height, base diameter and green weight per plant.

Mostafa et al., [14] reported that seventeen genotypes of Kenaf including three cultivated varieties; and fourteen genotypes of Mesta including one advanced line and one cultivated variety. A total of 272 crosses of Kenaf and 130 crosses of Mesta were made. Among them, 262 and 110 successful crosses were obtained from different cross combinations of Kenaf and Mesta respectively.

Mostafa et al., [15] reported that analysis of variance revealed significant differences among the treatments for all the traits studied at three locations except Manikganj for plant population and base diameter. All the tested lines showed lower yield than the check varieties HC-95 (3.63 t/ha) and BJRI Kenaf-3 (3.42 t/ha).

Ali et al., [16] reported that significant effect of different NPKS levels on BJRI Kenaf-4 yield and yield contributing characters over control. The highest fibre (3.14t/ha) and stick (7.65t/ha) yield were obtained by the combination dose of $\mathrm{N} 100 \mathrm{Kg} / \mathrm{ha}$ with PKS $10-60-20 \mathrm{~kg} / \mathrm{ha}$ at Kishoreganj. The plant height $(3.14 \mathrm{~m})$, base diameter $(19.47 \mathrm{~mm})$ also found highest with the same fertilizer treatment combination. By the same treatment produced higher fibre yield and yield contributing characters at Manikganj though that yield was slightly lower than Kishoreganj. Economic analysis suggested the best combination is N100-P10-K60-S20 $\mathrm{kg} / \mathrm{ha}$. The findings of the present experiment clearly indicated a great prospect of nutrient combination of N100-P10-K60-S20 kg/ha on the growth and yield of fibre production on the variety BJRI kenaf- 4 .

Islam [17] reported in a review article that Jute, kenaf and mesta fibre cultivation, trade and industry provide sustenance to over 4 million people of Bangladesh. The productivity of jute had doubled from $1.50 \mathrm{t} / \mathrm{ha}$ during 1970-80 to about 2.04 t/ha during 2015-16. Development of high-yielding varieties were the one of the main specific technologies which made this possible. Nearly 8 lack hectares of land cultivated by jute and allied crops per year in Bangladesh, which produced 80-90 lack bales of fibre. Over all 49 jute and allied varieties (White jute 25, Tossa jute 17, Kenaf 4 and Mesta 3 varieties) developed by BJRI. CVL-1, BJRI Deshi Pat-5, BJRI Deshi Pat-6, BJRI Deshi Pat-7, BJRI Deshi Pat-8, BJRI Deshi Pat Shak-1 and BJRI Deshi Pat-9 of C. capsularis L., O-9897, BJRI Tossa Pat-4, BJRI Tossa Pat-5, BJRI Tossa Pat-6, BJRI Tossa Pat-7 of $C$. olitorius L., HC2, HC-95, HC-3 and BJRI Kenaf-4 of Hibiscus canabinus and HS-24, BJRI Mesrta-2 and BJRI Mesta-3 of $H$. subdariffa. found important could cultivated in farmers field.

Ali et al. [18] was conducted an experiment to determine the effects of 


\section{J Nutrition and Food Processing}

inorganic fertilizer on growth, yield and economic potential yield contributing characters over control. The highest fibre (3.10t/ha) and stick (7.20t/ha) yield were obtained by the combination dose of $\mathrm{N} 100 \mathrm{Kg} / \mathrm{ha}$ with PKS $10-60-20 \mathrm{~kg} / \mathrm{ha}$ at Manikganj. The plant height $(3.08 \mathrm{~m})$, base diameter $(20.10 \mathrm{~mm})$ also found highest with the same treatment of fertilizer combination. By the same treatment produced higher fibre yield and yield contributing characters at Kishoreganj though that yield was slightly lower than that of Manikganj location. Economic analysis favored the use of 100-10-60-20 kg/ha NPKS for yield of 3.10 t/ha Mesta fibre.

Mollah et al. [19] reported that seed germination percentage, seed vigor index (SVI), germination (\%) after AA and EC values were found highly significant due to planting time, method and their interaction. It was found in interaction that the best quality seeds with germination $(95.75 \%$ and 90.25\%), seed vigor index (54.72 and 49.37), Electro-Conductivity value (13.21 and $14.19 \mu \mathrm{scm}-1 \mathrm{~g}-1)$ and Accelerated Ageing (AA) germination percentage $(76.0 \%$ and $72.75 \%$ ) were recorded when the seeds were sown on 30 July at transplanting method in both the years.

Mollah et al. [20]found that seed vigour through accelerated ageing, electro-conductivity and field emergence were affected significantly due to seed moisture content at different month of testing during the period of storage. At each of the observation period it was found that the accelerated ageing and field emergence decreased and electro-conductivity value increased with increasing initial seed moisture content. The highest values were found with seed having $8 \%$ initial seed moisture content (SMC) in both 2011 and 2012. Seed vigour values through accelerated ageing, electro-conductivity and field emergence of kenaf seed at different months of testing during storage period varied significantly. The accelerated ageing, field emergence percentage decreased and electro-conductivity increased with time of storage. Seed vigour by accelerated ageing, electroconductivity and field emergence differed significantly due to interaction of initial seed moisture content and storage container. The present study concludes that kenaf seeds could be stored in aluminum foil bag, plastic pot, polythene bag and tin container at 8 and $10 \%$ moisture content for up to 12 months of harvesting.

Mollah et al. [21]reported that seed germination percentage and vigour index were affected significantly due to seed moisture content at different month of testing during the period of storage. Aluminum foil bag, plastic pot, polythene bag and tin container at $8 \%$ and $10 \%$ moisture maintained more than $80 \%$ germination after 12 months of storage while those stored at $12 \%$ maintained above $80 \%$ germination for up to 6 month. On the other hand, seeds stored in aluminum foil bag, plastic pot, polythene bag and tin container at $14 \%$ SMC reached below $80 \%$ germination after 8 months of storage. Germination percentage and seed vigour index and moisture content of kenaf seed at different months of testing during storage period varied significantly. The seed stored in earthen pots at 8 and $10 \%$ SMC maintained above $80 \%$ germination for 2 months while those stored at 12 and $14 \%$ were failed. The present study concludes that kenaf seeds could be stored in aluminum foil bag, plastic pot, polythene bag and tin container at 8 and $10 \%$ moisture content for up to 12 months after completing postharvest processing.

Mollah et al. [22] conducted experiment and reported that the yield and yield attributes differed significantly due to planting date and methods. The highest seed yield (144.90 and $143.50 \mathrm{gm}^{-2}$ ) were recorded when the seeds were sown on 30 July at transplanting method in both the years. The lowest seed yield $\left(47.30\right.$ and $\left.57.01 \mathrm{gm}^{-2}\right)$ was observed from the plants of 30 September sowing with top cutting method. Plant height, base diameter, number of pod plant ${ }^{-1}$, number of seed pod $^{-1}$ and 1000 -seed weight had positive significant correlation with seed yield. Gross return, gross margin and BCR were calculated higher in transplanting method.

\begin{tabular}{|l|c|c|c|c|c|c|c|c|}
\hline Properties & Hemp & Jute & Ramie & Coir & Sisal & Flax & Cotton & Kenaf \\
\hline Density g/cm3 & 1.48 & 1.46 & 1.5 & 1.25 & 1.33 & 1.4 & 1.51 & 1.4 \\
\hline $\begin{array}{l}\text { Tensile } \\
\text { Strength, MPa }\end{array}$ & $\begin{array}{c}550- \\
900\end{array}$ & $\begin{array}{c}400- \\
800\end{array}$ & 500 & 220 & $\begin{array}{c}600- \\
700\end{array}$ & $\begin{array}{c}800- \\
1500\end{array}$ & 400 & $\begin{array}{c}283- \\
800\end{array}$ \\
\hline $\begin{array}{l}\text { Modulus, } \\
\text { GPa }\end{array}$ & 70 & $10-30$ & 44 & 6 & 38 & $60-80$ & 12 & $21-60$ \\
\hline Specific (E/d) & 47 & $7-21$ & 29 & 5 & 29 & $26-46$ & 8 & - \\
\hline $\begin{array}{l}\text { Elongation at } \\
\text { failure, \% }\end{array}$ & 1.6 & 1.8 & 2 & $15-25$ & $2-3$ & $1.2-1.6$ & $3-10$ & 1.6 \\
\hline $\begin{array}{l}\text { Moisture } \\
\text { absorption, \% }\end{array}$ & 8 & 12 & $12-17$ & 10 & 11 & 7 & $8-25$ & 18 \\
\hline
\end{tabular}

Table 8: Properties of Hemp, Jute, Ramie, Coir, Sisal, Flax, Cotton and Kenaf

\section{Uses}

\section{i. Fiber Uses}

Kenaf has a unique combination of long bast and short core fibers which makes it suitable for a range of paper and cardboard products. Scientists at the ARS have tested several kenaf pulping techniques, with the pulps being used to make several grades of paper including newsprint, bond, coating raw stock and surfaced sized. Results have been positive, particularly in terms of paper quality, durability, print quality and ink absorption. Commercialization of kenaf for newsprint manufacturing is in its final stages. Commercial scale newsprint runs were conducted by the private sector in California, Texas and Florida. Newspapers made from kenaf pulp have been shown to be brighter and better looking, with better ink laydown, reduced ruboff, richer color photo reproduction and good print contrast. Quality analyses showed kenaf newsprint to have superior tear, tensile and burst ratings. Additionally, kenaf newsprint manufacturing requires less energy and chemicals for processing, an

Auctores Publishing-Volume 2(1)-010www.auctoresonline.org Page-9 important advantage, both economically and environmentally.

\section{ii. Forage Uses}

The top leafy portion of the kenaf plant is not useful for pulping. Therefore, this part of the plant would be useful as forage if harvest equipment could be practically adapted to a dual collection operation. Florida researchers found that immature plants at a height of $6 \mathrm{ft}$ contained up to $20 \%$ protein. The kenaf ensiled successfully, both alone and with corn, and the silage was acceptable to heifers. They also found that kenaf leaf, dried and ground into a meal, had a greater crude protein digestibility than that of alfalfa meal. The amino acid composition of kenaf leaves is similar to that of alfalfa. Oklahoma research showed that kenaf leaf and petiole (non-stalk) portions of the plant were readily consumed by lambs and contained low fiber and high $\mathrm{N}$ concentrations. Analysis of the leafy kenaf material showed values of $8.7 \% \mathrm{NDF}, 3.5 \% \mathrm{ADF}$ and $34.0 \% \mathrm{CP}$. Contrasted to this, total plant composition levels were $42.9 \%, 32.6 \%$ and 
J Nutrition and Food Processing

$17.1 \%$ respectively. Clearly, the leaf and petiole

portion of the plant contains the majority of the digestible nutrients.

\section{iii. Kenaf paper}

The most common process to make kenaf paper is using soda pulping before processing the obtained pulp in a paper machine.

The use of kenaf in paper production offers various environmental advantages over producing paper from trees. In 1960, the USDA surveyed more than 500 plants and selected kenaf as the most promising source of tree-free newsprint. In 1970, kenaf newsprint produced in the International Paper Company's mill in Pine Bluff, Arkansas, was successfully used by six U.S. newspapers. Printing and writing paper made from the fibrous kenaf plant has been offered in the United States since 1992. Again in 1987, a Canadian mill produced 13 rolls of kenaf newsprint which were used by four U.S. newspapers to print experimental issues. They found that kenaf newsprint made for stronger, brighter and cleaner pages than standard pine paper with less detriment to the environment. Due partly to kenaf fibres being naturally whiter than tree pulp, less bleaching is required to create a brighter sheet of paper. Hydrogen peroxide, an environmentally-safe bleaching agent that does not create dioxin, has been used with much success in the bleaching of kenaf.

An area of 1-acre $\left(4,000 \mathrm{~m}^{2}\right)$ of kenaf produces 5 to 8 tons of raw plant bast and core fibre in a single growing season. In contrast, 1 -acre $(4,000$ $\mathrm{m}^{2}$ ) of forest (in the US) produces approximately 1.5 to 3.5 tons of usable fibre per year. It is estimated that growing kenaf on 5,000 acres $\left(20 \mathrm{~km}^{2}\right)$ can produce enough pulp to supply a paper plant having a capacity of 200 tons per day. Over 20 years, 1 -acre $\left(4,000 \mathrm{~m}^{2}\right)$ of farmland can produce 10 to 20 times the amount of fiber that 1 -acre $\left(4,000 \mathrm{~m}^{2}\right)$ of Southern pine can produce.

As one of the world's important natural fibres, kenaf is covered by the International Year of Natural Fibres 2009. The first novel to be published using 100\% kenaf paper was The Land of Debris and the Home of Alfredo by Kenn Amdahl (1997, Clearwater Publishing Company). David Brower, former Executive Director of the Sierra Club, in chapter 8 of his semiautobiographical environmental book Let the Mountains Talk, Let the Rivers Run: A Call to Save the Earth (1995, Harper Collins), titled "Forest Revolution," advocated for kenaf paper use and explained its many advantages over wood pulp. The first edition of the book was printed on kenaf paper.

\section{iv. Food and Medicinal Uses}

Where kenaf is grown in home gardens for fiber, the more tender upper leaves and shoots are sometimes eaten either raw or cooked. Kenaf fruits have significant medicinal properties, particularly for lowering blood pressure by helping increase nitric oxide and reducing oxidized lipids in the blood. They are very high in vitamin-C, antioxidants and phytochemicals, and have been found useful in treating metabolic diseases such as atherosclerosis, liver disease, cancer and diabetes, The seeds are a good source of fat slouble antioxidants [23].

Future Approach

Development and searching to be continued for-

- Less thermo and photo-sensitivity, especially allowing more flexibility of sowing and harvesting time with optimum biomass formation of Kenaf,

- Tolerance to problem soil (e.g. salinity, soil toxicity, wet foot condition etc.),

- Tolerance to diseases and pests;

- Having small seed size with long duration of seed viability of Kenaf,

- Smoothness and indehiscence type of kenaf fruits and
- Superior quality of kenaf fibre producing characteristics for diversified end uses.

\section{Conclusion}

There are so many kenaf crop varieties developed, released and used at farmer's level for commercial cultivation. All those varieties have high fibre and biomass yielding values. The kenaf fibre is snow white in colour same as white jute. In Bangladesh day by day demand of kenaf fibre is increasing. Kenaf uses in fibre, forage, paper pulp and also where kenaf is grown in home gardens, the more tender upper leaves and shoots are sometimes eaten either raw or cooked. Kenaf fruits have significant medicinal properties, very high in vitamin-C, antioxidants and phytochemicals. It's seeds are a good source of fat slouble antioxidants. In future research to be continued for searching kenaf varieties tolerance to problem soil; tolerance to diseases and pests; having small seed size with long duration of seed viability and smoothness and indehiscence type of kenaf fruits.

\section{References}

1. Mostafa MG (2012) Genetic divergence combining ability, Heterosis and gene action for yield characters in kenaf (Hibiscus cannabinus L.). Ph. D Thesis, Dept. Genet. \& Pl. Breed. Bangladesh Agril. Univ. Mymensingh, Bangladesh. P. 14.

2. Miyake B and Suzuta I (1937) Hibiscus cannabinus L. Formosan Agr. Rev.368: 591-597.

3. Dempsey JM (1975) Fibre crops. The university press of Florida, 15 Northwest 15th Street, Gainesville, Florida 32603.pp. 131-202.

4. Wilson FD, TE Summers, J.F. Joyner, D.W. Fishler, and C.C. Seale. (1965) 'Everglades 41' and 'Everglades 71', two new cultivars of kenaf (Hibiscus cannabinus L.) for the fiber and seed. Florida Agr. Expt. Sta. Cir. S-168.

5. Nieschlag HJ, GH Nelson, and I.A. Wolff. (1961) A search for new fiber crops, VI. Kenaf composition. TAPPI 44: 515-516.

6. White GA, DG Cummins, EL Whiteley, WT Fike, JK Greig, et al (1970) Cultural and harvesting methods for kenaf. USDA Prod. Res. Rpt. 113. Washington, DC.

7. Nelson GH, HJ Nieschlag, and IA Wolff 1962 A search for new fiber crops, V. Pulping studies on kenaf. TAPPI 45:780-786.

8. Webber CL III and RE Bledsoe (1993) Kenaf: Production, harvesting, and products. p. 416-421. In: J. Janick and J.E. Simon (eds.), New crops. Wiley, New York.

9. Bates DM 1965 Notes on the cultivated Malvaceae: Hibiscus. Baileya.13: 56-129.

10. MEDINA JC 1959 Plantsfibrosasdafloramundial.InstitutoAgronomico.Campanas, $\mathrm{Br}$ azil.

11. Popova GM (1928) A contribution to the morphology and biology ofHibiscus cannabinus L. Bul. Appl. Bot.19: 493-496.

12. Islam MM (2019) Varietal Advances of Jute, Kenaf and Mesta crops in Bangladesh: A review. International Journal of Bioorganic Chemistry. International Journal of Bioorganic Chemistry. 4(1): 24-41.

13. Mamun MA, Mostofa MG and Saha CK, (2016-2017) Screening of kenaf genetic resources against salinity. Ann. Res. Report (Agril. Res. On Jute) Bangladesh Jute Res. Insi. Pp. 65-67.

14. Mostofa MG, Mamun MA, and Saha CK (2017.) Hybridization among the selected genotypes of kenaf, mesta and their genotypes. Ann. Res. Report (Agril. Res. On Jute) Bangladesh Jute Res. Insi. 2017: 72-75.

15. Mostofa MG, Mamun MA and Saha CK (2017-2018b) Preliminary yield trial of kenaf breeding lines. Ann. Res. Report (Agril. Res. On Jute) Bangladesh Jute Res. Insi. Pp. 79-81.

16. Ali MS, Gani MN and Islam MM (2017) Efficiency of BJRI Kenaf-4 Yield Under Different Fertilizer Levels, American J. Agril. Forestry. 5(5): 145-149. 
17. Islam MM (2019) Food and Medicinal Values of Roselle (Hibiscus sabdariffa L. Linne Malvaceae) Plant Parts: A Review. Open J Nutr Food Sci. 1(1): 1003.

18. Ali MS, Hoque M, Gani MN and Islam MM (2017) Variation in Inorganic Fertilizer Is an Important Regulator of Yield Potential in BJRI Mesta-3. American Journal of Environmental Engineering and Science. 4(6): 78-84.

19. Mollah MAF, Islam MM, Rahman MS, Kamruzzaman M and Haque SMA (2015) Quality of Kenaf Seed as Influenced by Planting date and Method. Int. J. Sustain. Agril. Tech. 11(11): 1014.

20. Mollah MAF, Islam MM, Hossain MS, Rahman ML, and Rahman (2015b) Electrical Conductivity, Accelerated Aging and Field Emergence Tests of Kenaf (Hibiscuss cannabinus L) Seed Quality as affected by storage container and seed moisture content. Int. J. Sustain. Agril. Tech. 11(10): 01-09.

21. Mollah MAF, Rahman MM, Islam MM, Tareq MZ and Hossain MS (2015) Assessment of Kenaf (Hibiscuss cannabinus L) seed quality as affected by storage container and seed moisture content. Int. J. Sustain. Agril. Tech. 11(9): 06-14.

22. Mollah MAF, Islam MM, Rahman MS, Tareq MZ and Haque SMA (2015) Yield and cost of Kenaf seed production as influenced by Planting date and Method. Int. J. Sustain. Agril. Tech. 11(12): 0106.

23. Webber CL and VK Bledsoe (2002) Kenaf yield components and plant composition. In: J.Janick and A. Whipkey (eds.), Trends in new crops and new uses. ASHS Press, Alexandria, VA.pp.348357. 